Jurnal Sistem Informasi (Journal of Information Systems). 2/10 (2014), 83-86

DOI: http://dx.doi.org/10.21609/jsi.v10i2.390

\title{
APLIKASI ADMINISTRATIF SURAT MENYURAT MENGGUNAKAN METODOLOGI PEMODELAN BERBASIS OBJEK
}

\section{Harry Purnomo dan Nani K. Tachjar}

Teknik Informatika, Fakultas Teknologi Informasi, IKPIA Perbanas, Jl. Perbanas, Karet Kuningan, Setiabudi Jakarta Selatan, 12940, Indonesia

E-mail: harry.kanemoto@gmail.com,nanitachjar@gmail.com

\begin{abstract}
Conventional correspondence system or the so-called administrative system often makes its applicants frustrated. Once the letter is made, there should be a signature of the competent authority to legalize the letter. If these officials cannot be found immediately, then the signing of a letter will be delayed. Correspondence system in this article takes a case study in IKPIA Perbanas, especially the demand letter from a student. This study discusses about the system current usage, the evaluation, and the proposed system to solve some problems found. According to the procedure, the formal letter request should be processed within three days from the requested day. But in fact, the time required may be longer than it should be. Thus, when students need it in urgent circumstances, this cannot be accommodated by the system adopted IKPIA Perbanas. Solution to solve this problem is to implement a system developed using the object-based modeling method. This method is widely used in such systems and has a quite well performance.
\end{abstract}

Keywords: unified modelling language, digital signature, authorization, letter request

\begin{abstract}
Abstrak
Sistem surat menyurat atau umum disebut sistem administratif ini seringkali membuat pemohon surat mengalami keputus-asaan. Setelah surat dibuat, harus ada tanda tangan dari pejabat berwenang untuk melegalkan surat tersebut. Bila pejabat ini tidak dapat ditemui segera, maka penandatanganan surat akan tertunda. Sistem administratif surat menyurat dalam artikel ini mengambil studi kasus di IKPIA Perbanas, khususnya permintaan surat keterangan mahasiswa yang dipotret dari mulai sistem yang berjalan, evaluasi, hingga sistem yang diusulkan. Sesuai prosedur, sistem permintaan surat keterangan ini akan diterima oleh mahasiswa dalam waktu 3 hari sejak tanggal permintaan. Namun pada kenyataannya, waktu yang dibutuhkan dapat lebih lama dari yang seharusnya. Oleh karenanya, ketika ada mahasiswa yang membutuhkannya dalam keadaan yang mendesak, hal ini tidak dapat diakomodir oleh sistem yang digunakan IKPIA Perbanas. Solusi untuk memecahkan masalah ini adalah dengan penerapan sistem yang dikembangkan dengan menggunakan metode pemodelan berbasis objek. Metode tersebut umum digunakan untuk memodelkan sistem sejenis administrative surat menyurat tersebut dan memiliki kinerja yang cukup baik.
\end{abstract}

Kata Kunci: unified modelling language, tanda tangan digital, otorisasi, pengajuan surat

\section{Pendahuluan}

Sistem administratif surat menyurat adalah kegiatan yang dianggap mudah. Namun ternyata kegiatan ini merupakan hal yang esensial, terlebih jika menyangkut dengan birokrasi pengurusan seperti permohonan beasiswa. Berhadapan dengan birokrasi merupakan hal yang acapkali membuat pemohon menjadi putus asa. Hal yang sama pun dihadapi oleh mahasiswa di IKPIA Perbanas. Oleh karenanya, seringkali kesempatan baik seperti pemberian beasiswa dari pihak luar terlewatkan begitu saja dikarenakan mahasiswa tidak memenuhi salah satu persyaratan yang diminta, yaitu surat keterangan mahasiswa.
Surat keterangan diperlukan oleh mahasiswa untuk memenuhi syarat-syarat yang dibutuhkan bukan hanya beasiswa, namun juga untuk permohonan lainnya. Mahasiswa harus melewati beberapa prosedur untuk mendapatkan surat keterangan ini. Prosedur awal permohonan surat keterangan dapat dipenuhi dan dilalui mahasiswa dengan mudah, dan masalah akan bermula saat permintaan tanda tangan ke pejabat yang berwenang untuk melegalkan surat tersebut.

Surat yang seharusnya ditandatangani akan tertunda bila pejabat yang memberikan otorisasi tidak berada di tempat. Sehingga waktu yang dibutuhkan untuk mendapatkan surat keterangan pun menjadi lebih lama dari yang seharusnya. Begitu 


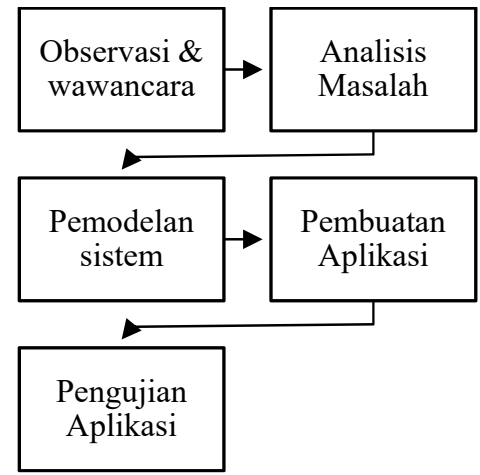

Gambar 1. Tahapan penelitian

pun dengan pengajuan surat bimbingan Kuliah Kerja Praktek (KKP) dan skripsi, yang mana ketika mahasiswa telah mengajukan surat namun pejabat berwenang tidak berada di tempat. Khusus untuk pengajuan proposal skripsi, mahasiswa diharuskan untuk memberikan proposal sebanyak 2 buah yang lalu dinilai layak atau tidak oleh Kaprodi sebagai pejabat yang berwenang. Permasalahan yang timbul kemudian, selain kehadiran Kaprodi yaitu waktu untuk pembuatan dan pengambilan surat. Oleh karena itu, dibuat aplikasi sistem administratif surat-menyurat sebagai solusi dari masalah ini. Pembuatan aplikasi sistem ini menggunakan pemodelan dengan berbasis objek atau Unified Modelling Language (UML) [4] dengan menambahkan otentifikasi dari para pemegang wewenang secara digital agar surat dapat disahkan tanpa terkendala waktu.

\section{Metode}

Penelitian ini menggunakan pendekatan metode kualitatif dengan menggali data maupun observasi dan mewawancarai para pemangku kepentingan yakni mahasiswa, staf Biro Kemahasiswaan, Staf Prodi, Staf Akademik, Kaprodi, Kabiro Kemahasiswaan dan Dosen Pembimbing. Gambar 1 merupakan tahapan yang dilakukan pada penelitian ini.

\section{Observasi}

Observasi dilakukan dengan mengamati terlebih dahulu proses dan prosedur mulai dari permintaan hingga pemberian surat keterangan kepada mahasiswa. Wawancara dilakukan bilamana ada prosedur dan proses yang kurang jelas atau kurang dapat dipahami. Melalui langkah ini ditemui adanya prosedur dan proses yang dapat diubah sehingga waktu tempuh untuk mendapatkan surat keterangan menjadi lebih singkat.

\section{Analisis Masalah}

Analisis masalah dilakukan berdasarkan hasil dari tahapan observasi serta wawancara. Atas dasar kegiatan yang dilakukan, dicari upaya-upaya untuk mengatasi masalah berupa kendala waktu menunggu untuk mendapatkan surat keterangan.

\section{Pemodelan Sistem}

Sistem yang berjalan dan telah dianalisis sebelumnya dimodelkan dengan menggunakan pemodelan berbasis objek. Pemodelan dengan UML menggunakan dua diagram, yaitu; activity diagram dan use case diagram. Sedangkan untuk sistem usulan menggunakan diagram berupa activity, use case, sequence, collaboration dan class diagram.

\section{Pembuatan Aplikasi}

Tahap berikutnya adalah perancangan dan pembuatan aplikasi. Pada tahap ini, perancangan sistem dibuat berdasarkan pemodelan sistem yang telah dilakukan sebelumnya. Hubungan antartabel dan database dibuat dengan panduan dari class diagram.

\section{Pengujian Aplikasi}

Tahap pengujian aplikasi dilakukan dengan menggunakan parameter waktu yang menghitung pelaksanaan proses awal hingga surat keterangan diterima oleh mahasiswa.

\section{Pemodelan Berbasis Objek}

Pemodelan sistem dapat dilakukan dengan menggunakan dua metode. Metode yang pertama adalah dengan menggunakan pemodelan terstruktur, yaitu dengan Diagram Alir Data atau Data Flow Diagram (DFD). Adapun pemodelan yang kedua yaitu Unified Modelling Language (UML) atau yang kerapkali disebut dengan pemodelan berbasis objek.

Menurut Tegarden [1], UML adalah teknik menggambarkan diagram standar yang menyediakan representasi grafik untuk memodelkan proyek sebuah sistem dari mulai analisis hingga implementasi. Sedangkan menurut Kimmel [2], UML adalah pemodelan perangkat lunak dengan menggunakan simbol-simbol dan diagram. UML sendiri memiliki beraneka diagram untuk me-modelkan sistem yang berorientasi obyek namun, diagram yang umum digunakan untuk memodel-kan sistem adalah use case, activity, class, sequence dan collaboration diagram.

\section{Hasil dan Analisis}

Hasil yang dapat ditarik dari analisis masalah adalah sistem yang digunakan saat ini pada dasarnya 
TABEL1

SPESIFIKASI AKTOR DALAM SISTEM USULAN

\begin{tabular}{lll}
\hline Nama Aktor & Deskripsi & Tanggung Jawab \\
\hline Mahasiswa & $\begin{array}{l}\text { Mendapatkan fasilitas } \\
\text { untuk pengajuan } \\
\text { pembuatan surat } \\
\text { kemahasiswaan }\end{array}$ & Tidak ada \\
Staff Admi- & $\begin{array}{l}\text { Memproses dan } \\
\text { menyiapkan } \\
\text { nistratif }\end{array}$ & $\begin{array}{l}\text { Mengelola pem- } \\
\text { buatan surat ke- } \\
\text { mahasiswaan }\end{array}$ \\
surat kemahasiswaan & \\
Kaprodi & $\begin{array}{l}\text { Menyetujui atau } \\
\text { menolak pengajuan } \\
\text { surat dengan jenis } \\
\text { surat pengajuan KKP, } \\
\text { surat pengajuan dosen } \\
\text { pembimbing KKP } \\
\text { dan Pengajuan skripsi }\end{array}$ & $\begin{array}{l}\text { Mengotentifikasi } \\
\text { pengajuan surat }\end{array}$ \\
& $\begin{array}{l}\text { Menyetujui atau } \\
\text { menolak pengajuan } \\
\text { surat dengan jenis } \\
\text { surat keterangan } \\
\text { mahasiswa }\end{array}$ & $\begin{array}{l}\text { Mengotentifikasi } \\
\text { pengajuan surat }\end{array}$ \\
$\begin{array}{l}\text { Kabiro } \\
\text { Kemaha- } \\
\text { siswaan }\end{array}$ & $\begin{array}{l}\text { Mengontrol dan } \\
\text { mengatur jalannya } \\
\text { sistem administrasi } \\
\text { surat menyurat }\end{array}$ & $\begin{array}{l}\text { Mengelola apli- } \\
\text { kasi sistem ad- } \\
\text { ministrasi surat- } \\
\text { menyurat }\end{array}$ \\
Administra- \\
tor
\end{tabular}

cukup baik. Hanya saja, masih terdapat prosedur yang dapat dimaksimalkan. Salah satu contoh terdapat pada proses pengajuan surat, yang mana dalam sistem yang berjalan saat ini, kehadiran pimpinan (Kaprodi, Kabiro kemahasiswaan) di tempat untuk tanda tangan masih sangat diperlukan.

Selain itu, terjadi penumpukan kertas surat yang sudah dicetak disebabkan permintaan akan surat namun, mahasiswa yang tidak mengambil surat yang sudah dipesan sehingga menyebabkan pemborosan kertas.

Prosedur ini akan lebih baik lagi jika dilakukan melalui sistem satu pintu yaitu; melalui sebuah aplikasi yang khusus melayani pengajuan surat kemahasiswaan sehingga proses dapat dilakukan dengan otomatis dan proses pembuatan surat pun dapat lebih cepat.

\section{Sistem Usulan}

Perancangan sistem usulan dimulai men-deskripsikan aktor dan tanggung jawab yang diembannya, dilanjutkan dengan membuat skenario untuk penjabaran prosedur usulan. Spesifikasi aktor dalam sistem usulan ini dapat dilihat pada Tabel 1.

Adapun skenario penggunaan aplikasi bagi setiap pengguna untuk sistem administratif suratmenyurat ini dibagi dalam beberapa bagian sebagai berikut.
TABEL 2

\begin{tabular}{|c|c|c|c|}
\hline \multirow{2}{*}{ No } & \multirow{2}{*}{ Proses } & \multicolumn{2}{|c|}{ Waktu $( \pm)$} \\
\hline & & Lama & Baru \\
\hline \multirow[t]{5}{*}{1} & $\begin{array}{l}\text { Mengisi Formulir untuk } \\
\text { peng-ajuan surat: }\end{array}$ & & \\
\hline & $\begin{array}{l}\text { a. Surat Keterangan } \\
\text { Mahasiswa }\end{array}$ & $10 \mathrm{mnt}$ & $10 \mathrm{mnt}$ \\
\hline & b. Surat Pengajuan KKP & $5 \mathrm{mnt}$ & $5 \mathrm{mnt}$ \\
\hline & $\begin{array}{l}\text { c. Surat Pengajuan Skripsi } \\
\text { dan Outline }\end{array}$ & $5 \mathrm{mnt}$ & $3 \mathrm{mnt}$ \\
\hline & $\begin{array}{l}\text { d. Surat Pengajuan Dosen } \\
\text { Pembimbing KKP dan } \\
\text { Outline KKP }\end{array}$ & $5 \mathrm{mnt}$ & $3 \mathrm{mnt}$ \\
\hline 2 & Periksa form surat pengajuan & $1 \mathrm{mnt}$ & $1 \mathrm{mnt}^{*}$ \\
\hline 3 & $\begin{array}{l}\text { Cetak Surat Keterangan } \\
\text { Mahasiswa, Surat Pengantar } \\
\text { atau surat kesediaan Dosen } \\
\text { Pembimbing KKP/Skripsi }\end{array}$ & $1 \mathrm{mnt}$ & $1 \mathrm{mnt}$ \\
\hline 4 & Verifikasi Data Mahasiswa & $5 \mathrm{mnt}$ & $1 \mathrm{mnt} *$ \\
\hline 5 & $\begin{array}{l}\text { Tanda tangan surat } \\
\text { keterangan, pengajuan KKP, } \\
\text { atau Surat Pengantar Dosen } \\
\text { Pembimbing KKP/Skripsi }\end{array}$ & $3 \mathrm{hr}$ & - \\
\hline 6 & $\begin{array}{l}\text { Periksa outline skripsi, atau } \\
\text { KKP }\end{array}$ & $15 \mathrm{mnt}$ & $15 \mathrm{mnt}$ \\
\hline 7 & $\begin{array}{l}\text { Penolakan Outline skripsi } \\
\text { atau KKP }\end{array}$ & $1 \mathrm{hr}$ & $1 \mathrm{mnt}$ \\
\hline \multirow[t]{2}{*}{8} & $\begin{array}{l}\text { Validasi Kaprodi atau Kabiro } \\
\text { berupa digital signature }\end{array}$ & - & $1 \mathrm{mnt}$ \\
\hline & Total Waktu & $\begin{array}{l}4 \mathrm{hr} 57 \\
\mathrm{mnt}\end{array}$ & $41 \mathrm{mnt}$ \\
\hline
\end{tabular}

* oleh sistem

Mahasiswa

Aplikasi ini akan dijalankan melalui web browser yang mana mahasiswa akan login sebelumnya. Dalam aplikasi ini, mahasiswa dapat mengajukan pembuatan surat ditujukan ke biro kemahasiswaan atau mengajukan proposal skripsi.

\section{Staf Administratif}

Staf Administratif memiliki kewenangan untuk membuat surat berdasarkan tiga kondisi, yaitu: pengajuan surat baru, surat belum otentifikasi dan surat sudah otentifikasi. Dalam kondisi pengajuan surat baru, staf akan mengirim surat kepada Kabiro/ Kaprodi tergantung jenis surat. Dalam kondisi surat belum otentifikasi, staf memberitahukan dengan cara mengirim notifikasi kepada kabiro/kaprodi bahwa ada surat yang belum diotentifikasi melalui aplikasi. Dalam kondisi surat sudah otentifikasi, staf akan mencetak surat.

Kaprodi

Kaprodi akan login ke aplikasi dengan memasukan NIP sebagai user id dan password. Dalam aplikasi ini Kaprodi dapat mengakses dan memilih permintaan otentifikasi berdasarkan tiga jenis surat, yaitu: surat keterangan mahasiswa, surat pengajuan KKP dan surat pengajuan dosen pembimbing KKP. Personal Identification Number (PIN) yang dimiliki Kaprodi diperlukan untuk mengotentifikasi surat. 
Kabiro Kemahasiswaan

Kabiro dapat mengakses aplikasi untuk memilih permintaan otentifikasi surat keterangan mahasiswa. Seperti halnya Kaprodi maupun Kabiro kemahasiswaan akan memerlukan PIN yang dimilikinya untuk mengotentifikasi surat.

\section{Administrator}

Administrator memiliki kewenangan penuh untuk menjalankan aplikasi dan memperbarui aplikasi.

\section{Hasil Uji Coba}

Aplikasi sistem surat-menyurat ini diujicobakan dengan mlakukan pengukuran menggunakan parameter waktu. Pengukuran dilakukan dengan membandingkan antara waktu sebelum (ketika masih menggunakan sistem lama) dan sesudah pemakaian aplikasi usulan. Hasil ini seperti terdapat pada Tabel 2. Berdasarkan hasil pengukuran waktu ini, didapatkan perbedaan yang signifikan yaitu berupa pengurangan waktu hingga $90 \%$.

\section{Kesimpulan}

Dengan aplikasi administrasi surat-menyurat ini semua kegiatan administratif yang berhubungan dengan mahasiswa dapat diintegrasikan, dimana surat yang dapat dibuat di antaranya adalah: surat keterangan mahasiswa, surat pengajuan KKP, surat pengajuan dosen pembimbing KKP, dan surat pengajuan skripsi. Selain itu, penolakan atas outline skripsi atau KKP dapat diketahui mahasiswa dengan lebih cepat. Sehingga dapat memotong birokrasi dan dapat mengurangi waktu untuk menyelesaikan surat-surat tersebut. Aplikasi ini masih dapat ditingkatkan dengan mengirimkan notifikasi berupa sms atau pun e-mail kepada mahasiswa jika penolakan, penerimaan outline atau permintaan surat telah selesai.

\section{Referensi}

[1] David Tegarden, Alan Dennis and Barbara Haley Wixom, Sistems Analysis and Design with UML. edisi ke-4, Singapore, 2013, hal. 43.

[2] Paul Kimmel, UML Demystified: A Self Teaching Guide. Ohio: McGraw-Hill Education, 2001

[3] Grady Booch, dkk. Object Oriented Analysis And Design With Applications. Edisi Ketiga, Massachusetts: Addison Wesley Longman, Inc. 2007

[4] Munawar, Pemodelan Visual dengan UML. Edisi Pertama, Yogyakarta: Graha Ilmu. 2005

[5] Al-Bahra Ladjamuddin. Konsep Sistem Basis Data dan Implementasinya. Edisi Pertama. Yogyakarta: Graha Ilmu. 2004 Theses, Dissertation

[6] Harry Purnomo, "Rancang Bangun Aplikasi Sistem Administrasi Surat Menyurat Berbasis Web pada IKPIA Perbanas", Skripsi, Teknik Informatika, IKPIA Perbanas, Jakarta, Indonesia, 2012. Conference Proceeding/Workshops

[7] B.D. Theelen, O. Florescu, M.C.W. Geilen, J. Huan, P.H.A. van der Putten, J.P.M. Voeten. Software/Hardware Engineering with the Parallel Object-Oriented Specification Language. MEMOCODE '07 Proceedings of the 5th IEEE/ACM International Conference on Formal Methods and Models for Codesign (Proceeding), Pages 139-148, IEEE Computer Society, Washington, DC, USA, 2007. 